\title{
Simultaneous Organic and Nutrient Removals from Industrial Dairy Wastewater Effluent by Integrating Membrane Bioreactor and Conventional Biological Treatment Process
}

\author{
S. B. Al-Shammari
}

\begin{abstract}
The objective of this work was to evaluate the effectiveness of integrated biological conventional treatment with membrane bioreactor (MBR) system in removing organic and nutrients from dairy industry wastewater. A pilot treatment system including biological treatment and submerged MBR system was installed at Kuwait Institute for Scientific Research (KISR) research plant. The integrated MBR system was operated at the following conditions: average influent flow rate of $1 \mathrm{~m} 3 / \mathrm{d}$, average sludge retention time (SRT) of $38 \mathrm{~d}$, and average hydraulic retention time (HRT) of $2 \mathrm{~h}$. The results clearly show the performance of the integrated system in removing organic matters with an average removal efficiency of 99\% for both biological oxygen demand (BOD) and chemical oxygen demand (COD). However, good reduction in nutrients concentration in the system effluent. The average reported efficiencies on total nitrogen (TN), ammonium (NH4-N) and total phosphorus (TP) were $45,44.8$ and $67.1 \%$, respectively.
\end{abstract}

Index Terms-Dairy, industrial wastewater, membrane, removal efficiency.

\section{INTRODUCTION}

Among the food industries, the dairy industry characteristically requires very large quantities of freshwater and generates large quantities of wastewater. It generates about $0.2-10 \mathrm{~L}$ of effluent per liter of processed milk with an average generation of about $2.5 \mathrm{~L}$ of wastewater per liter of the milk processed [1]. Most of the wastewater volume generated in the dairy industry results from cleaning of transport lines and equipment between production cycles, cleaning of tank trucks, washing of milk silos and equipment malfunctions or operational errors [2]-[4].

Dairy waste effluent is characterized by a high content of COD, BOD, fat, nutrients (nitrate and phosphate) and total suspended solid (TSS) [5]. Discharging dairy waste into receiving water body promote eutrophication and deplete the dissolved oxygen level and create anaerobic conditions and consequently strong foul odor is released [1]. Discharging dairy waste to the land produce harmful effects on the soil quality and can leach to underlying groundwater and therefore deteriorate its quality. It is, therefore, very important to treat dairy waste effluent in order to reduce the potential harm to the environment [6].

The conventional treatments of wastewater generated in

Manuscript received April 8, 2018; revised May 15, 2018.

Saud Al-Shammari is with the Environmental Health Departments, College of Health Science, The Public Authority for Applied Education and Training P. O. Box 14281, Faiha 72853, Kuwait (e-mail: s.b.alwan@gmail.com, salalwan@gmail.com). dairy industries include the use of primary treatment to remove solids and fats and biological treatment to eliminate organic matter and nutrients and in some cases tertiary treatment as polishing [3], [4], [7], and [8]. Among biological treatment methods which are commonly employed for dairy wastewater, sequencing batch reactor (SBR), up-flow anaerobic sludge blanket reactor, activated sludge plants and anaerobic treatment [9]. However, several problems have been reported, such as high production of scum, low sludge settleability and difficulties in removal of nutrients (nitrogen and phosphorus) [7]. In recent years several works demonstrated that application of MBR technologies were becoming more energy efficient as compared to conventional methods. [10]-[13]. MBR is an onsite wastewater treatment system that combines biological removal of nitrogen, phosphorus and BOD applying the activated sludge process with membrane submerged in the wastewater capable of filtering solids resulting in low turbidity permeate [14]. A clear advantage of MBR is the complete separation of the HRT and SRT, which eliminate operational limitations imposed on the conventional activated sludge process. This allows MBRs to be operated at low liquid HRT and long higher SRT without the wash-out of biomass. Therefore, an optimal control of biological reactions can be obtained by controlling the residence time of the microorganisms in the reactor. Attaining long sludge age is very important for the development of slow-growing microorganisms such as nitrifying bacteria [15]. This makes membrane separation in the bioreactor more attractive for situations where long SRT are necessary to achieve the removal of pollutants [16]. In addition MBR system has advantage of reduced footprint comparing to conventional treatment systems and production of clarified disinfected treated effluent which can be reused for many purposes [5]. The aim of this research work was to evaluate the feasibility of MBR system to treat and eliminate nutrients from dairy industry wastewater effluent.

\section{MATERIAL AND MethodS}

The wastewater used for this study came from a large Kuwaiti dairy factory (KD Cow Company) which produces a variety of dairy foods such as milk, cheese, ice cream, cream, butter, etc. Wastewater is primarily washwater resulting from cleaning and sanitizing equipment; thus, it contains some dairy product. Water from general cleanup and hosing down plant facilities ends up in the drains as does rejected fluid from the cleaning in-place (CIP) operations. In addition, product spills of various kinds frequently end up in the floor 
drains and therefore, become part of the wastewater. The average wastewater generated from $\mathrm{KD}$ Cows dairy processing plant is $620 \mathrm{~m}^{3} / \mathrm{d}$ which is drained to a waste pit then collected by a wastewater tanker.

\section{A. Experimental Setup}

The complete system for wastewater treatment involves the integration of membrane separation and conventional biological treatment processes. The system consisted of 4 membrane modules with total area of $52 \mathrm{~m}^{2}$ and utilizes hollow fiber membranes to provide a self-cleaning system. The pilot system diagram is shown in Fig. 1. The biological treatment occurs in the aerobic system. This system includes aeration tank and adjacent air blower which injects an adequate air into the aeration tank. The aerobic system in which biological treatment includes the process air blowers which are installed adjacent to the system. The required process air flow is $63 \mathrm{~L} / \mathrm{s}$ introduced at the bottom of the aerobic tank through air scour distribution header pipes. After passing through the upstream flow, the mixed liquor is transferred by overflow to a suitable buffer flow tank and then pressurized to an operating pressure in accordance with the membrane's design. In order to reduce any oder in the feed water, the treated effluents is forced to flow through PAC. The filtration process takes place from the outer surface of the fiber to the hollow inner core. Feed liquid passes through the porous wall of the fibers, and suspended matter remains on the feed side. To clean membrane surface and therefore restore the filtration flow rate, the membrane is backwashed. During backwash, filtration is stopped and air is applied to the outside of the fibers. A small amount of filtrate is pushed through the fibers to further remove deposits from the outer surface of the fibers. The tank is then drained to transport any dislodged deposits to the clarifier tank for the separation of any solid particles. The sludge will settle at the bottom of the clarifier. The overflow from the clarifier will be recycled to the aeration tank for further treatment to prevent fermentation of the backwash water.

\section{B. Analytical Method}

All parameter determinations in the laboratory were performed according to outlined Standard Methods for Water and Wastewater [18]. Both chemical and biological analyses were carried out at the laboratories of KISR Sulaibiya Wastewater Research Plant. Furthermore, the analysis results were cross checked randomly with KISR Central Analytical Laboratory (CAL) as quality assurance.

\section{RESULTS AND DISCUSSION}

\section{A. Operating Conditions}

The operating parameters, such as $\mathrm{pH}$, temperature, feed pressure, flow rate, feed conductivity and turbidity, were monitored and recorded daily. At the beginning of the experimental testing program the pilot system was tested under variable operating conditions to determine the optimal operating conditions of the system. The operating factors of the MBR system are shown in Table I. The concentrations of BOD and COD in the dairy processing effluents vary widely, from 450 to $1035 \mathrm{mg} / \mathrm{L}$ and 879 to $2575 \mathrm{mg} / \mathrm{L}$, respectively. Organic loading rate (OLR) ranged between 0.9 to $2.5 \mathrm{~kg}$ $\mathrm{COD} / \mathrm{m}^{3} . \mathrm{d}$ with an average value of $1.47 \mathrm{~kg} \mathrm{COD} / \mathrm{m}^{3} . \mathrm{d}$.

\begin{tabular}{lll}
\multicolumn{2}{c}{ TABLE I: OPERATIONAL CONDITIONS OF THE TREATMENT SYSTEM } \\
\hline \hline Parameters & Range & Mean $\pm \boldsymbol{S D}$ \\
\hline Temperature, ${ }^{\circ} \mathrm{C}$ & $24.9-41.3$ & $33 \pm 1.4$ \\
Conductivity $(\mu \mathrm{S} / \mathrm{cm})$ & $945-1710$ & $1267 \pm 269$ \\
$\mathrm{pH}$ & $6.4-7.6$ & $7.0 \pm 0.4$ \\
$\mathrm{Turbidity}(\mathrm{NTU})$ & $18-200$ & $94 \pm 55$ \\
$\mathrm{NH}_{4}-\mathrm{N}(\mathrm{mg} / \mathrm{l})$ & $3.2-18.6$ & $8.9 .30 \pm 3.9$ \\
$\mathrm{TN}(\mathrm{mg} / \mathrm{L})$ & $7.9-26.2$ & $15 \pm 5.1$ \\
$\mathrm{PO}_{4}{ }^{-}(\mathrm{mg} / \mathrm{L})$ & $1.4-6.4$ & $3.7 \pm 1.5$ \\
$\mathrm{BOD}^{(\mathrm{mg} / \mathrm{L})}$ & $450-1035$ & $715 \pm 173$ \\
$\mathrm{COD}(\mathrm{mg} / \mathrm{L})$ & $879-2575$ & $1473 \pm 448$ \\
OLR $\left(\mathrm{kg} \mathrm{COD} / \mathrm{m}^{3} . \mathrm{d}\right)$ & $0.9-2.5$ & $1.47 \pm 0.45$ \\
$\mathrm{HRT}, \mathrm{h}$ & $2.0-2.2$ & $2.0 \pm 0.2$ \\
$\mathrm{SRT}, \mathrm{d}$ & $34-47$ & $38 \pm 0.7$ \\
Flux $\left(1 / \mathrm{m}^{2} / \mathrm{h}\right)$ & $14-24$ & $19 \pm 1.3$ \\
\hline \hline
\end{tabular}

During commissioning period, operating parameters were optimized to achieve best performance of the biological treatment system. The optimized parameters were flowrate, HRT, SRT, dissolved oxygen (DO) and MLSS. The biological treatment system was operated with aerobic (capacity $6 \mathrm{~m}^{3}$ ) and anoxic (capacity $6 \mathrm{~m}^{3}$ ) tanks, and with a flux range of 14 to $24 \mathrm{~L} / \mathrm{m}^{2} / \mathrm{h}$ and an HRT of $2 \mathrm{~h}$. The system was operated without activated sludge wasting to allow the MLSS to increase in the aeration tank. The sludge wasting rate was set to give an SRT in the range of 34 to $47 \mathrm{~h}$. The average TSS recorded in the aeration tank was $120 \mathrm{mg} / \mathrm{L}$, with maximum and minimum values of 274 and $10 \mathrm{mg} / \mathrm{L}$, respectively. The DO concentrations in the biological treatment ranged from 2.0 to $2.7 \mathrm{mg} / \mathrm{L}$ and from 0.1 to 0.7 $\mathrm{mg} / \mathrm{L}$, in the aerobic and anoxic tanks, respectively.

\section{B. Removal of Organic Matter}

Fig. 2 shows the influent, effluent and removal efficiency of BOD throughout the evaluated period. The influent BOD averaged $720 \mathrm{mg} / \mathrm{L}$, and ranging from $450-1000 \mathrm{mg} / \mathrm{L}$. BOD concentration in the effluent varied from $2.5-6 \mathrm{mg} / \mathrm{L}$ with an average value of $4 \mathrm{mg} / \mathrm{L}$, corresponding to average removal efficiency of $99 \%$.

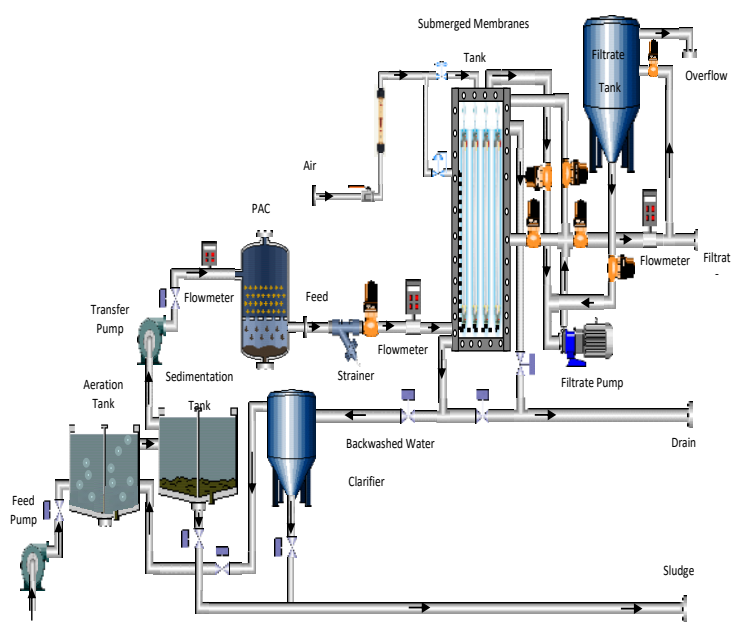

Fig. 1. Integrated treatment system.

Similar to BOD, excellent COD removal efficiencies were noticed during the testing period. As shown in Fig. 3 the 
influent COD averaged $1470 \mathrm{mg} / \mathrm{L}$, and ranging from $870-2500 \mathrm{mg} / \mathrm{L}$. COD concentration in the effluent varied from $3.5-35 \mathrm{mg} / \mathrm{L}$ with an average value of $12 \mathrm{mg} / \mathrm{L}$, corresponding to average removal efficiency of $99 \%$.

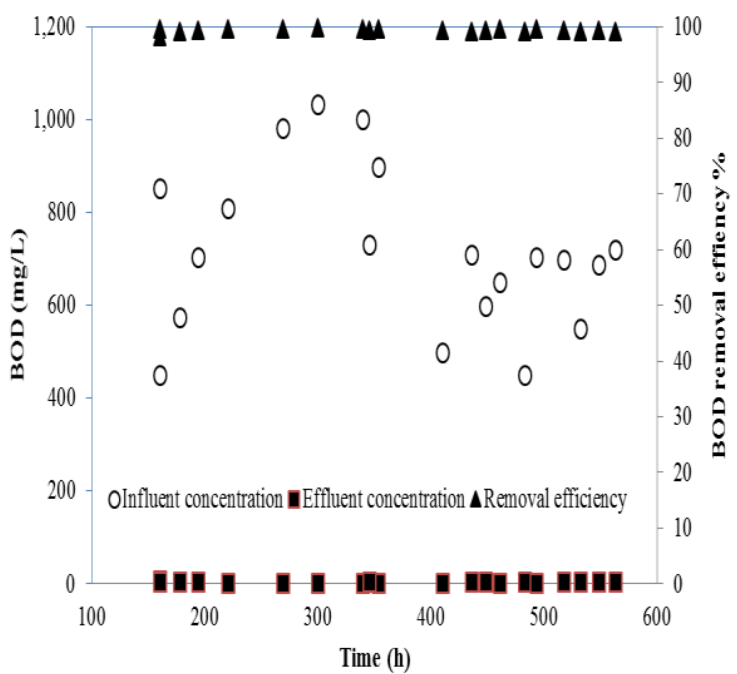

Fig. 2. BOD influent, effluent and removal efficiencies.

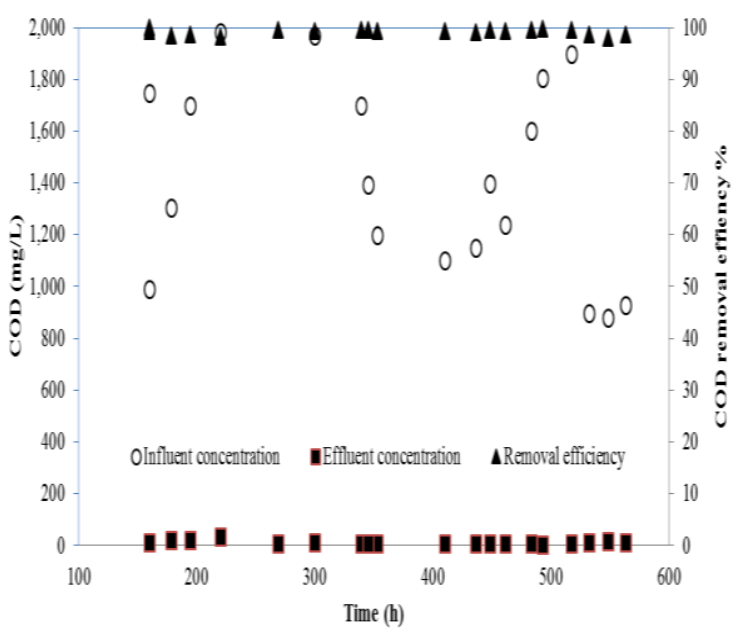

Fig. 3. COD influent, effluent and removal efficiencies.

The results show almost complete reduction in both COD and BOD values comparing to influent measurements which clearly indicates the efficiency of the MBR system in removing organic matters. Better biodegradation of the organic matters occurred due to solids barrier provided by the membrane in the integrated system. Similar results were obtained by many authors who found that, when a conventional treatment system combined with MBR is used to treat dairy wastewater, a readily biodegradable organic compounds can be effectively removed [5]. In a previous study a COD removal efficiencies between 94 and $99 \%$ were obtained during treatment of whey produced in a dairy factory [17]. The system which been used consisted off an aerobic jet loop reactor coupled to membranes. Another work show the feasibility of aerobic MBR system for the treatment of dairy industry wastewater. The authors obtained organic matter removal efficiency of $99 \%$. It is clear that the organic matter removal efficiencies reported in this study are similar to those presented in other related studies [18].

\section{Removal of Nitrogen}

Total nitrogen removal in wastewater treatment plants is achieved in two step processes: nitrification followed by denitrification. In the first step ammonia is converted into nitrate under aerobic conditions, which is then converted to nitrogen gas in subsequent denitrification process [19]. Fig. 4 and 5 shows the influent, effluent and removal efficiency of $\mathrm{NH}_{4}-\mathrm{N}$ and $\mathrm{TN}$, respectively. The influent concentration of $\mathrm{NH}_{4}-\mathrm{N}$ averaged $8.9 \mathrm{mg} / \mathrm{L}$, and ranging from 3.2-19 mg/L. Whereas $\mathrm{NH}_{4}-\mathrm{N}$ concentration in the effluent varied from 1.6-10.1 mg/l with an average value of $4.7 \mathrm{mg} / \mathrm{L}$, corresponding to average removal efficiency of $44.8 \%$.

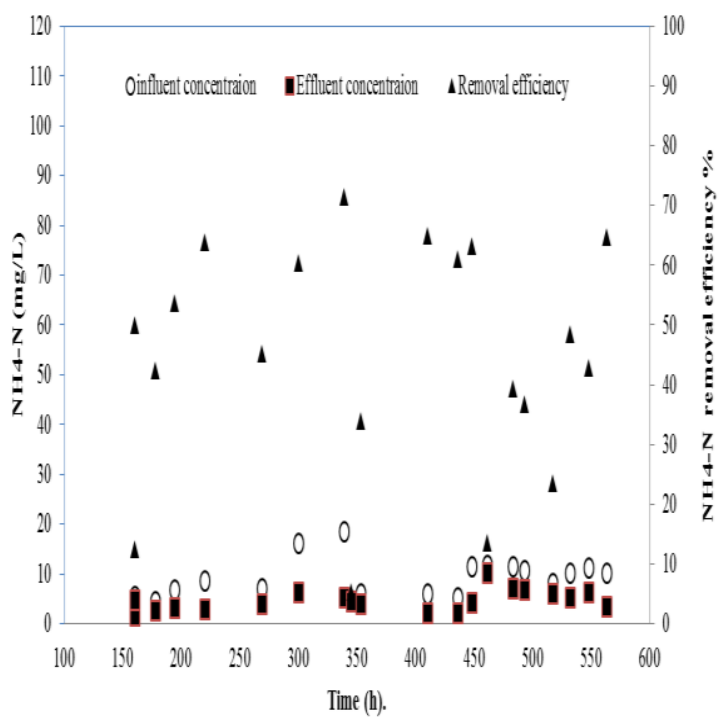

Fig. 4. NH4-N influent, effluent and removal efficiencies.

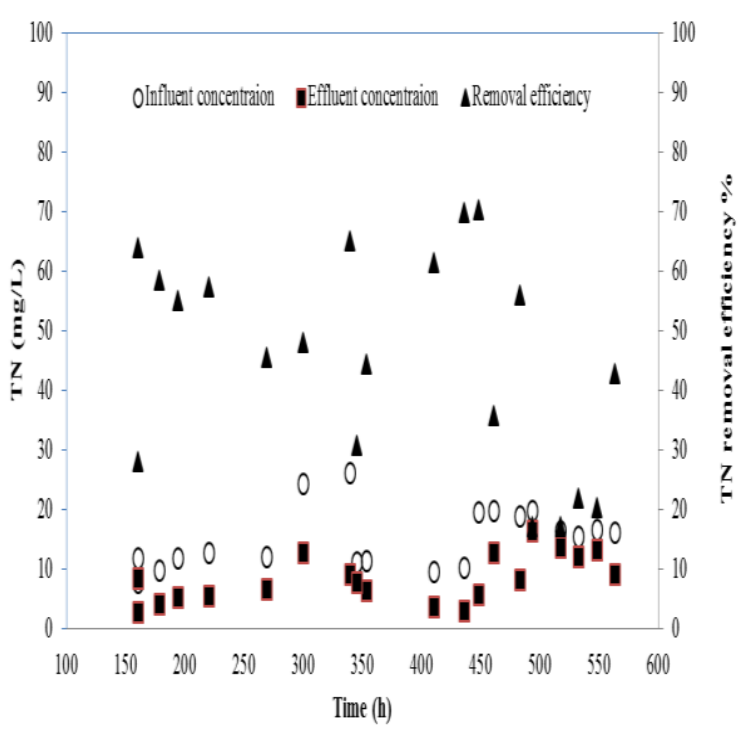

Fig. 5. TN influent, effluent and removal efficiencies.

As can be seen in Fig.5 influent TN concentration in the range of 8 to $26 \mathrm{mg} / \mathrm{L}$ with average value of $15.1 \mathrm{mg} / \mathrm{L}$. TN concentration in the effluent varied from $2.8-16.4 \mathrm{mg} / \mathrm{L}$ with an average value of $8.3 \mathrm{mg} / \mathrm{L}$. The percentage removal of TN was ranged from $17.3 \%$ to $69.4 .3 \%$ with an average value of $45 \%$. The average removal of $\mathrm{TN}$ was low and similar to that of $\mathrm{NH}_{4}-\mathrm{N}$ and this result indicates that the nitrification/ denitrification processes was limited. This limitation reveals that the conventional part of the system was unable to perform nitrification/denitrification processes under aerobic and anoxic conditions, respectively. Similar results were 
observed by many researchers investigating nutrient removal from dairy wastewater. They found that to ensure complete nitrification extra second anoxic zone after aeration was useful to reduce TN concentration in the effluent. [20].

\section{Removal of Phosphorous}

Although, the pilot MBR system was not designed specifically for biological removal of phosphorus, the efficiency of the MBR system in removing TP was tested. Fig. 6 shows the variation of TP concentration for the influent, effluent and percentage removal of phosphate occurred in the system. The influent TP was fluctuating during the period of operation between $6 \mathrm{mg} / \mathrm{L}$ and $22 \mathrm{mg} / \mathrm{L}$ with an average value of $17.3 \mathrm{mg} / \mathrm{L}$. TP concentration in the effluent was varied from 1.9-6.2 mg/L with an average value of $3.9 \mathrm{mg} / \mathrm{L}$. As observed in Fig. 6 the removal efficiency of TP was ranged between $23.3 \%$ and $91.1 \%$ with an average value of $67.1 \%$ which revealed that the TP was not efficiently removed from the effluent. In biological phosphorus removal process, the phosphorus in the influent is incorporated into cell biomass, which eventually is removed from the process as a result of sludge wasting. Therefore, TP removal depends on the mass of sludge wasted, which is ultimately governed by the SRT of the system, and the P content of the wasted biomass [19]. As shown in Table I the average SRT applied in this study was $38 \mathrm{~d}$. this may explain the incomplete removal of TP from the effluent. Many authors have shown similar findings to this study and they noticed that the MBR system was not efficient for biological removal of phosphorous [5].

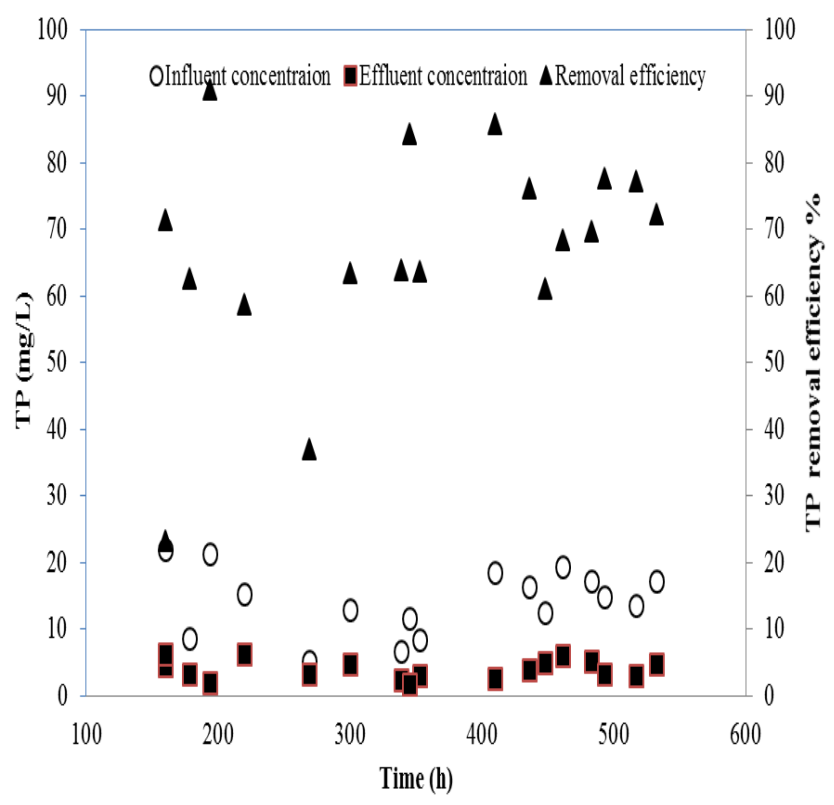

Fig. 6. TP influent, effluent and removal efficiencies.

\section{CONCLUSIONS}

In this study, industrial dairy wastewater rich in organic matters and nutrients was treated using combined conventional and MBR system. Results of this study indicate that the system was very effective in removing organic matters with observed BOD and COD removal efficiencies of $99 \%$. However, biological removal of nutrients show incomplete nitrification/denitrification processes and NH4-N and TN were present in treated effluent of TN. The average removal efficiencies for $\mathrm{NH}_{4}-\mathrm{N}$ and $\mathrm{TN}$ were $44.8 \%$, and $45 \%$, respectively. Better performance was reported for TP with average removal efficiency of $67.1 \%$. The conventional part of the system need to be improved in order to increase nitrification/denitrification rate and therefore enhance biological removal of nitrogen compounds.

\section{ACKNOWLEDGEMENTS}

The author would like to express his gratitude to the Kuwait Foundation for the Advancement of Sciences for the partial funding of the project and to Kuwait Dairy Company for their cooperation in implementing this project.

\section{REFERENCES}

[1] C. S. Jyothi and A. G. Bindu, "Feasibility of anaerobic fluidized membrane bioreactor (AFMBR) in the treatment of dairy wastewater - A review" International Journal of Innovative Research in Science and Engineering, vol. 3, issue 1, pp. 363-369, 2017.

[2] K. B. Askaran, L. M. Palmowskiand, and B. M. Watson, "Wastewater reuse and treatment options for the dairy industry," Water Science and Technology, vol. 3, pp. 85-91, 2003.

[3] J. R. Danalewich, T. G. Papagiannis, R. L. Belyea, and M. E. L. Raskin, "Characterization of dairy waste streams, current treatment practices, and potential for Biological nutrient removal," Water Research, vol. 32, pp. 3555-3568, 1998.

[4] G. Vidal, A. Carvalho, R. Mendez, and J. M. Lema, "Influence of the content in fats and Proteins on the anaerobic biodegradability of dairy wastewaters," Bio-resource Technology, vol. 74, pp. 231-239, 2000.

[5] F. A. Fraga, H. A. García, C. M. Hooijmans, D. Míguez, and D. Brdjanovic, "Evaluation of membrane bioreactor on dairy wastewater treatment and reuse in Uruguay," International Biodeterioration \& Biodegradation, vol. 119, pp. 552-564, 2017.

[6] W. Shu-Mei and L. Jun-Xin, "Enhanced biological nutrients removal using an integrated oxidation ditch with vertical circle from wastewater by adding an anaerobic column," Journal of Environmental Sciences, vol. 17 , no. 6 . pp. 894-898, 2005.

[7] L. H. Andrade, F. D. S. Mendes, J. C. Espindola, and C. S. Amaral, "Reuse of dairy wastewater treated by membrane bioreactor and nanofiltraion: Technical and economic feasibility," Brazilian Journal of Chemical Engineering, vol. 32, no. 3, pp. 735-747, 2015.

[8] B. Kasapgil, G. K. Anderson, and O. Ince, "An investigation into the pretreatment of dairy wastewater prior to aerobic biological treatment," Water Science Technology, vol. 29, pp. 205-212, 1994.

[9] B. Demirel, O. Yenigun, and T. T. Onay, "Anaerobic treatment of dairy wastewaters," Process Biochemistry, vol. 40, pp. 2583-2595, 2005.

[10] V. Mavrov, H. Chmiel, and E. Belieres, "Spent process water desalination and organic removal by membranes for water reuse in the food industry," Desalination, vol. 138, pp. 65-74, 2001.

[11] V. Yip, S. D. Arnsfield, and A. W. Hydamaka, "Potential for stainless steel microfiltration processing to reduce effluent from a fluid milk and ice cream processing plant," Journal of Dairy Science, vol. 79, pp. 710-716, 1996.

[12] B. D. Blanchard, "Plant effluents dairy waste streams recovery," Dairy, Food and Environmental Sanitation, vol. 11, no. 9, pp. 494-496, 1991

[13] I. Koyuncu, M. Turan, D. Topacik, and A. Ates, "Application of low pressure nanofiltration membranes for the recovery and reuse of dairy industry effluents," Water Science and Technology, vol. 41, no. 1, pp. 213-221, 2000.

[14] M. Sharrer, K. Rishel, and S. T. Summerfelt, "Evaluation of a membrane biological reactor for reclaiming water, alkalinity, salt, phosphorus and protein contained in a high-strength aquacultural wastewater," Bioresource Technology, vol. 101, pp. 4322-4330, 2010.

[15] M. Green, E. Gidron, M. Beliavski, O. Lahav, and S. Tarre, "Treatment of dairy wastewater using a vertical bed with passive aeration," Environmental Technology, vol. 25, no. 10, pp. 1123-1130, 2004.

[16] Environmental Public Authority Kuwait (EPA), "Wastewater criteria for disposal," 2001.

[17] B. Farizoglu, B. Keskinler, E. Yildiz, and A. Nuhoglu, "Cheese whey treatment performance of an aerobic jet loop membrane bioreactor," Process Biochem., vol. 39, pp. 2283-2291, 2004.

[18] D. Sharma, "Treatment of dairy waste water by electro coagulation using aluminum electrodes and settling, filtration studies," 
International Journal of Chemical Technology Research, vol. 6, no. 1 , pp. 591-599, 2014.

[19] M. Kermani, B. Bina, H. Movahedian, M. Amin, and M. Nikaeen, "Biological phosphorus and nitrogen removal from wastewater using moving bed biofilm process," Iranian Journal of Biotechnology, vol. 7, no. 1, pp. 19-27, 2009.

[20] R. Pannirselvam, Y. Ibrahim, and N. Gopalakrishnan, "Simultaneous carbon and nutrient removal from dairy wastewater in sequencing batch reactor (SBR)," Global NEST Journal, vol. 17, pp. 628-636, 2015.

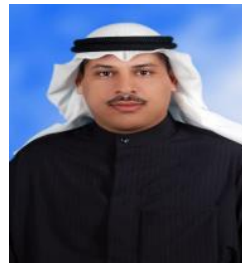

Saud B. Al-Shammari was born in the State of Kuwait. In 2002 he received his Ph.D. degree in chemical engineering from Manchester University, UK. After graduation, he was scientific researcher at Water Technologies Department in Kuwait Institute for Scientific Reseach (KISR). Since 2010 to now, he has been professor associate at Environmental Health Department in Public Authority for Applied
Education and Training. His research interests include water and wastewater treatment, environmental engineering and seawater desalination. He has published more than 28 scientific articles which were published in international journals. 